Article

\title{
Fibroblast Fatty-Acid Oxidation Flux Assays Stratify Risk in Newborns with Presumptive-Positive Results on Screening for Very-Long Chain Acyl-CoA Dehydrogenase Deficiency
}

\author{
Simon E. Olpin ${ }^{1, *}$, Shirley Clark ${ }^{1}$, Jane Dalley ${ }^{1}$, Brage S. Andresen ${ }^{2}$, Joanne Croft ${ }^{1}$, \\ Camilla A. Scott ${ }^{1}$, Aneal Khan ${ }^{3}$, Richard J. Kirk ${ }^{4}$, Rebecca Sparkes ${ }^{3}$, Marisa Chard ${ }^{3}$, \\ Alicia Chan ${ }^{5}$, Emma Glamuzina ${ }^{6}$, Jean Bastin ${ }^{7}$, Nigel J. Manning ${ }^{1}$ and Rodney J. Pollitt ${ }^{1}$ \\ 1 Department of Clinical Chemistry, Sheffield Children's Hospital Sheffield, Sheffield S10 2TH, UK; \\ shirley.clark@sch.nhs.uk (S.C.); jane.dalley@sch.nhs.uk (J.D.); joanne.croft@sch.nhs.uk (J.C.); \\ camilla.scott@sch.nhs.uk (C.A.S.); evemanning@talktalk.net (N.J.M.); rodney.pollitt@sch.nhs.uk (R.J.P.) \\ 2 Department of Biochemistry and Molecular Biology, University of Southern Denmark, \\ DK-5230 Odense M, Denmark; bragea@bmb.sdu.dk \\ 3 Department of Medical Genetics \& Paediatrics, Alberta Children's Hospital, Calgary, AB T3B 6A8, Canada; \\ khaa@ucalgary.ca (A.K.); rebecca.sparkes@ahs.ca (R.S.); marisa.chard@ahs.ca (M.C.) \\ 4 Department of Molecular Genetics, Sheffield Children's Hospital, Sheffield S10 2TH, UK; \\ richard.kirk@sch.nhs.uk \\ 5 Department of Medical Genetics, University of Alberta, Calgary, AB T3B 6A8, Canada; \\ alicia.chan@albertahealthservices.ca \\ 6 National Metabolic Service, Starship Children's Hospital, Auckland 1042, New Zealand; \\ eglamuzina@adhb.govt.nz \\ 7 Inserm U747, Université Paris Descartes, UFR Biomédicale des Saints-Pères, 75270 Paris CEDEX 06, France; \\ jean.bastin@inserm.fr \\ * Correspondence: simon.olpin@sch.nhs.uk; Tel.: +44-114-271-7267
}

Academic Editor: Ralph Fingerhut

Received: 13 January 2017; Accepted: 17 February 2017; Published: 24 February 2017

\begin{abstract}
Very-long chain acyl-CoA dehydrogenase deficiency (VLCADD) is a clinically heterogeneous disorder with three major phenotypes: severe neonatal/infantile, milder childhood and late onset myopathic. VLCADD is genetically heterogeneous with numerous pathogenic mutations and variants of uncertain significance. VLCADD is included in many newborn screening programs but these suffer from high false positive rates, primarily due to positive screens in heterozygotes. Separating these and newborns with two low-risk "mild" variants from clinically at risk patients can be problematic, as clinical and biochemical markers are often unreliable, particularly in stable neonates. We have measured fibroblast fatty acid oxidation flux using $\left[9,10-\mathrm{H}^{3}\right]$ myristic acid and $\left[9,10-\mathrm{H}^{3}\right]$ oleic acid from 69 clinically presenting VLCADD patients including myopathic and infantile phenotypes and 13 positive newborn screened patients. We also measured fibroblast VLCADD enzyme activity by UV-HPLC detection of product in a sub-set of patients and compared these results to oleate FAO-flux. Fibroblast enzyme assay by UV-HPLC detection failed to clearly discriminate between some clinically presenting VLCADD patient cell lines and cell lines from some simple heterozygotes. FAO-flux clearly discriminated between clinically presenting VLCADD patients and the false positive screened patients. FAO-flux at $37^{\circ} \mathrm{C}$ provides information as to the likely clinical phenotype but FAO-flux at $41^{\circ} \mathrm{C}$ is the best discriminator for identifying clinically at risk patients.
\end{abstract}

Keywords: VLCAD very long chain acyl-CoA dehydrogenase; newborn screening; false positive; oleic acid oxidation; fatty acid oxidation flux; enzyme assay 


\section{Introduction}

Newborn (NB) screening programs in much of Europe and in other countries around the world including the USA, Canada, New Zealand and Australia include very long-chain acyl-CoA dehydrogenase deficiency (VLCADD OMIM 201475) [1-5]. Currently, the only fatty acid oxidation disorder included in the UK newborn screening program is medium chain acyl-CoA dehydrogenase (MCAD OMIM 201450) deficiency [6].

VLCADD can present with three major phenotypes: a severe neonatal/infantile form, with early onset non-ketotic hypoglycemia, a high incidence of cardiomyopathy and high mortality; a milder childhood form, usually with hypoketotic hypoglycemia as the main presenting feature, often with exercise intolerance; and rhabdomyolysis, particularly in older children, and a late onset myopathic form in adults $[7,8]$.

Newborn screening for VLCADD suffers from a high false positive rate due to false positive results in many heterozygotes and to elevated acylcarnitines including C14:1 in some catabolic neonates even in the absence of $A C A D V L$ mutations. In addition, presumptive positive screened patients are often treated before a definitive diagnosis is established and biochemical markers of disease may diminish or even normalize $[9,10]$. There is considerable molecular heterogeneity of $A C A D V L$ with new variants of uncertain significance and mild mutations resulting in significant residual enzyme function. This, in conjunction with unreliable biochemical markers, not infrequently poses real difficulties in separating infants at risk of disease from those who do not require continued intervention or follow up [11-13]. Functional assays such as very long-chain acyl-CoA dehydrogenase (VLCAD) activity in lymphocytes or acylcarnitine profiles following palmitate loading in fibroblasts are useful tools in these difficult cases, though they are by no means always definitive [11,14-17]. Some patients even in the presence of two $A C A D V L$ mutations may have relatively high residual lymphocyte enzyme activity and are considered to be at low risk of disease [11]. Fibroblast fatty acid oxidation studies using $\left[9,10-\mathrm{H}^{3}\right]$ oleic acid alone or in combination with other tritiated fatty acids have been proposed as offering an improved alternative approach in the differential classification of these patients [18-21]. In this study, we report fatty acid oxidation flux (FAO-flux) by measuring $\left[9,10-\mathrm{H}^{3}\right]$ myristic acid and $\left[9,10-\mathrm{H}^{3}\right]$ oleic acid oxidation in fibroblast cell lines from several patient groups and compare results of FAO-flux with fibroblast VLCADD enzyme activity.

\section{Patients}

Over the past 25 years, we have received 69 fibroblast cell lines from clinically symptomatic patients in whom we could confirm a diagnosis of VLCADD. Patients presenting either as neonates/infants/young children with primarily cardiomyopathy and/or hypoglycemic episode(s) were classified as "infantile" VLCADD $(n=47)$ and patients diagnosed as older children/adults with myalgia/exercise intolerance/rhabdomyolysis were classified as "myopathic" VLCADD $(n=22)$. We have also received fibroblast cell lines from 13 presumptive positive neonates from centers outside the UK that routinely undertake newborn screening for VLCAD deficiency. Eight of these were shown on full genetic and biochemical investigation not to have supportive evidence of VLCADD; i.e., only one or no mutation founds ( 5 cell lines), homozygous for the common "benign" Pacific mutation (c.1226C > T; p.Thr409Met) (2 cell lines) [5], or second mutation of unknown significance with enzyme activity by UV-HPLC $>100 \%$ ( 1 cell line). These therefore were termed false positives (eight cell lines in total, Table 1).

Three newborn screened patients were considered true positives. One patient was a sibling of a previous symptomatic neonate that died on Day 1 with two pathogenic mutations in the ACADVL gene (cell line 12). The second was a neonate with one known pathogenic mutation plus a predicted pathogenic mutation (cell line 233). A third patient (cell line 18) presented with one mutation of unknown pathogenicity plus one predicted pathogenic mutation and enzyme activity measured by UV-HPLC of $11 \%$ (Table 1). 
Table 1. Clinical and biochemical data from positive NBS patients, symptomatic adults and obligate heterozygotes.

\begin{tabular}{|c|c|c|c|c|c|c|c|c|c|}
\hline $\begin{array}{l}\text { Cell } \\
\text { Line }\end{array}$ & $\begin{array}{c}\text { Age at Time of } \\
\text { Investigation/Diagnosis }\end{array}$ & $\begin{array}{l}\text { Detail/Presumed } \\
\text { Diagnosis }\end{array}$ & $\begin{array}{l}\text { NBS Cut off and Day } \\
\text { of Screen C14:1 } \\
\mu \mathrm{mol} / \mathrm{L}<0.6 \text { Day } 1\end{array}$ & Mutation & $\begin{array}{c}37^{\circ} \mathrm{C} \\
\text { Oleate } \%\end{array}$ & $\begin{array}{c}41^{\circ} \mathrm{C} \\
\text { Oleate } \%\end{array}$ & $\begin{array}{l}\text { HPLC } \\
\%\end{array}$ & Current Age & Follow Up \\
\hline 77 & Neonate & $\begin{array}{l}\text { False positive screen } \\
1 \text { mutation only }\end{array}$ & 1.11 & $\begin{array}{c}\text { Heterozygous } \\
\text { c.848T }>\text { C (p.Val283Ala) }\end{array}$ & 70 & 66 & 84 & $\begin{array}{l}6 \text { years } 7 \\
\text { months }\end{array}$ & $\begin{array}{l}\text { Asymptomatic; } 10 \text { month } \\
\text { follow up }\end{array}$ \\
\hline 78 & Neonate & $\begin{array}{l}\text { False positive screen } \\
1 \text { mutation only }\end{array}$ & 1.21 & $\begin{array}{c}\text { Heterozygous } \\
\text { c.1316G >A (p.Gly439Asp) }\end{array}$ & 66 & 70 & 40 & $\begin{array}{l}6 \text { years } 8 \\
\text { months }\end{array}$ & $\begin{array}{l}\text { Asymptomatic; } 10 \text { month } \\
\text { follow up }\end{array}$ \\
\hline 76 & Neonate & $\begin{array}{l}\text { False positive screen } \\
1 \text { mutation only }\end{array}$ & 0.79 & $\begin{array}{c}\text { Heterozygous } \\
\text { c.848T }>\text { C (p.Val283Ala) }\end{array}$ & 93 & 134 & 87 & $\begin{array}{l}6 \text { years } 9 \\
\text { months }\end{array}$ & Asymptomatic; 9 month follow up \\
\hline 37 & Neonate & $\begin{array}{l}\text { False positive screen } \\
1 \text { mutation only }\end{array}$ & 1.21 & $\begin{array}{c}\text { Heterozygous } \\
\text { c.897G }>\text { C (p.Lys299Asn) }\end{array}$ & 74 & 83 & 29 & $\begin{array}{l}6 \text { years } 10 \\
\text { months }\end{array}$ & Remains asymptomatic \\
\hline 91 & Neonate & $\begin{array}{l}\text { False positive screen } \\
2 \text { mutations }\end{array}$ & 1.08 & $\begin{array}{l}\text { c.1405C>T (p.Arg469Trp) } \\
\text { c.686G >A (p.Arg229Gln) }\end{array}$ & 66 & 66 & 117 & $\begin{array}{c}5 \text { years } 9 \\
\text { months }\end{array}$ & $\begin{array}{l}\text { Asymptomatic; } 5 \text { year } 2 \text { month } \\
\text { follow up }\end{array}$ \\
\hline \multirow[t]{2}{*}{78} & Neonate & $\begin{array}{l}\text { False positive screen } \\
\text { No mutation }\end{array}$ & 0.91 & No mutations detected & 90 & 93 & 138 & $\begin{array}{l}6 \text { years } 10 \\
\text { months }\end{array}$ & Asymptomatic; 8 month follow up \\
\hline & & & $\begin{array}{l}{ }^{*} \text { NBS cut off } \\
<1.3 \text { Day } 2\end{array}$ & & & & & & \\
\hline 17 & Neonate & False positive screen & 2.14 & $\begin{array}{c}\text { Homozygous } \\
\text { c.1226C >T (p.Thr409Met) }\end{array}$ & 120 & 126 & 70 & $\begin{array}{l}4 \text { years } 6 \\
\text { months }\end{array}$ & Well. No more ER. Discharged \\
\hline 519 & Neonate & False positive screen & 2.98 & $\begin{array}{c}\text { Homozygous } \\
\text { c.1226C > T (p.Thr409Met) }\end{array}$ & 122 & 155 & NA & $\begin{array}{l}5 \text { years } 2 \\
\text { months }\end{array}$ & Well. No more ER. Discharged \\
\hline 12 & Neonate & $\begin{array}{l}\text { True positive screen. Treated } \\
\text { from birth. Previous sib died } \\
\text { of VLCAD on day } 1 \text { of life }\end{array}$ & 5.45 & $\begin{array}{l}\text { c.942_947delAGTACG } \\
\text { (p.Arg316_Val317del) } \\
\text { c.343delG (p.(Glu115fs)) }\end{array}$ & 8 & 8 & NA & $\begin{array}{l}4 \text { years } 1 \\
\text { month }\end{array}$ & $\begin{array}{l}\text { Severe infantile: Treated from birth } \\
\text { with MCT and ++ calories. High } \\
\text { CK despite high calorie and MCT } \\
\text { diet and overnight feeding }\end{array}$ \\
\hline 233 & Neonate & $\begin{array}{l}\text { True positive screen. } \\
\text { Avoidance of fasting, } \\
\text { emergency regimen }\end{array}$ & 6.9 & $\begin{array}{c}\text { c.848T>C (p.Val283Ala) } \\
\text { c.1616C }>\text { A (p.Ala539Asp })\end{array}$ & 29 & 16 & NA & $\begin{array}{l}3 \text { years } 10 \\
\text { months }\end{array}$ & $\begin{array}{c}\text { On normal diet, max fasting time } \\
\text { of } 12 \mathrm{~h}+\text { ER. Yearly CK, Liver USS, } \\
\text { echo. Asymptomatic }\end{array}$ \\
\hline 18 & Neonate & True positive screen & 8.2 & $\begin{array}{c}\text { c.622G }>C \text { (p.Gly208Arg) } \\
\text { last nucleotide in } \\
\text { exon-likely to be splicing } \\
\text { mutation. } \\
\text { c.1838G }>\text { A (p.Arg613Gln) }\end{array}$ & 29 & 17 & 11 & $\begin{array}{l}4 \text { years } 2 \\
\text { months }\end{array}$ & $\begin{array}{l}\text { Loose low fat, high MCT diet. } \\
\text { Short fasting time. Strict ER. At } 4 \\
\text { years, resting CK increased, corn } \\
\text { starch introduced }\end{array}$ \\
\hline
\end{tabular}


Table 1. Cont

\begin{tabular}{|c|c|c|c|c|c|c|c|c|c|}
\hline $\begin{array}{l}\text { Cell } \\
\text { Line }\end{array}$ & $\begin{array}{c}\text { Age at Time of } \\
\text { Investigation/Diagnosis }\end{array}$ & $\begin{array}{l}\text { Detail/Presumed } \\
\text { Diagnosis }\end{array}$ & $\begin{array}{c}\text { NBS Cut off and Day } \\
\text { of Screen C14:1 } \\
\mu \mathrm{mol} / \mathrm{L}<0.6 \text { Day } 1\end{array}$ & Mutation & $\begin{array}{c}37^{\circ} \mathrm{C} \\
\text { Oleate } \%\end{array}$ & $\begin{array}{c}41^{\circ} \mathrm{C} \\
\text { Oleate } \%\end{array}$ & $\underset{\%}{\text { HPLC }}$ & Current Age & Follow Up \\
\hline 16 & Neonate & $\begin{array}{l}\text { Uncategorised } \\
\text { positive screen }\end{array}$ & 3.81 & $\begin{array}{l}\text { c.1226C }>\text { T (p.Thr409Met) } \\
\text { c.1616C >A (p.Ala539Asp) }\end{array}$ & 63 & 64 & NA & $\begin{array}{l}4 \text { years } 5 \\
\text { months }\end{array}$ & $\begin{array}{l}\text { Well. No medical problems } \\
\text { No diet. Self-discharged }\end{array}$ \\
\hline 22 & Neonate & $\begin{array}{l}\text { Uncategorised positive } \\
\text { screen. Avoidance of fasting, } \\
\text { emergency regimen }\end{array}$ & 2.73 & $\begin{array}{l}\text { c.1226C > T (p.Thr409Met) } \\
\text { c.1322G >A (p.Gly441Asp) }\end{array}$ & 56 & 21 & 24 & $\begin{array}{l}4 \text { years } 9 \\
\text { months }\end{array}$ & Well. Discharged \\
\hline 52 & \# Symptomatic adult & $\begin{array}{l}\text { Uncategorised. Single } \\
\text { episode of hyperthermia and } \\
\text { rhabdomyolysis following } \\
\text { unaccustomed extended } \\
\text { aerobic exercise, became } \\
\text { encephalopathic, } \\
\text { hospitalised and developed } \\
\text { multi-organ failure. No } \\
\text { biochemical markers } \\
\text { suggestive of VLCAD. CPT2 } \\
\text { deficiency excluded }\end{array}$ & $\begin{array}{l}\text { Within normal } \\
\text { reference range }\end{array}$ & $\begin{array}{c}\text { Heterozygous } \\
\text { c.1837C }>\text { T (p.Arg613Trp) }\end{array}$ & 56 & 46 & 38 & & \\
\hline 19 & \# Symptomatic adult & $\begin{array}{l}\text { Uncategorised. Atypical } \\
\text { neurological symptoms not } \\
\text { suggestive of VLCAD. No } \\
\text { history of hypoglycaemia or } \\
\text { rhabdomyolysis. CPT2, } \\
\text { LCHAD, TFP also excluded }\end{array}$ & $\begin{array}{l}\text { Within normal } \\
\text { reference range }\end{array}$ & $\begin{array}{c}\text { Heterozygous } \\
\text { c.1019G }>\text { T (p.Gly340Val) } \\
\text { + c.753-27C }>\text { T Possible } \\
\text { double mutant allele, } \\
\text { identical genotype detected } \\
\text { in an unrelated newborn } \\
\text { (unpublished data) }\end{array}$ & 55 & 46 & 21 & & \\
\hline 32 & Adult & obligate heterozygote & NA & $\begin{array}{c}\text { Heterozygous } \\
\text { c.1360G }>\text { A (p.Asp454Asn) }\end{array}$ & 107 & NA & NA & & Asymptomatic \\
\hline 33 & Adult & obligate heterozygote & NA & $\begin{array}{c}\text { Heterozygous } \\
\text { c.1375C }>\text { T (p.Arg459Trp) }\end{array}$ & 103 & NA & NA & & Asymptomatic \\
\hline 34 & Adult & obligate heterozygote & NA & $\begin{array}{c}\text { Heterozygous } \\
\text { c.848T }>\mathrm{C} \text { (p.Val283Ala) }\end{array}$ & 51 & 52 & 32 & & Asymptomatic \\
\hline 35 & Adult & obligate heterozygote & NA & None detected & 71 & 63 & 87 & & Asymptomatic \\
\hline
\end{tabular}

Red, known pathogenic mutation; NA, data not available/not analyzed; \# [20]; ER, emergency regimen; CK, creatine kinase; MCT, medium chain triglyceride; CPT2, carnitine palmitoyltransferase type 2; LCHAD, long-chain 3-hydroxyacyl-CoA dehydrogenase deficiency; TFP, trifunctional protein deficiency; NB, Two obligate carriers gave oleate flux $>100 \%$ of controls at $37{ }^{\circ} \mathrm{C}$ and therefore were not assayed at $41{ }^{\circ} \mathrm{C}$ and not included in this table; ${ }^{*}$ Current cut-off is $\mathrm{C} 14: 1 \geq 2.5$. 
Informed Consent: Informed consent was obtained from all patients, their parents or legal guardians prior to obtaining skin biopsies for fibroblast studies in countries where this was required by law.

Two infantile patients remain uncategorized as both have a copy of the common "benign" Pacific c. $1226 \mathrm{C}>\mathrm{T}$ mutation plus one other mutation [5]. In one uncategorized case, the second mutation is a known pathogenic mutation (cell line 22) and in the other case the second mutation is of unknown pathogenicity (cell line 16) (Table 1). Two adults with clinical disease possibly attributable to reduced VLCAD activity also remained uncategorized as both were shown to have at least one mutation in the VLCAD gene (Table 1). We also included four adult obligate heterozygotes, i.e., parents of a VLCAD patient.

\section{Methods}

Flux assays were performed in multi-well plates and each assay measured FAO-flux in 9 patient cell lines ( 2 substrates in duplicate, 4 wells for each patient) as previously described $[18,22,23]$. Results were calculated in pmol $\mathrm{H}_{2} \mathrm{O} \mathrm{h}^{-1}$ (mg fibroblast protein) ${ }^{-1}$ and the cumulative data for the assay used to calculate the percentage activity towards each substrate for each cell line. Cell lines with activities $<70 \%$ towards either of the two substrates were then removed from the calculation and the remaining cell lines designated as simultaneous normal controls. The simultaneous normal control results were used to generate a mean normal control activity for each substrate. Cell line(s) from patients with reduced FAO-flux were expressed as percentage activity of the assay normal control mean for each substrate. Each assay generally consisted of 5-8 simultaneous normal control cell lines. Every cell line was assayed at least twice and VLCADD cell lines and screen positive cell lines were assayed up to 12 times. Fibroblasts were routinely grown and assayed at $37^{\circ} \mathrm{C}$, but some cell lines were also grown and assayed at $41^{\circ} \mathrm{C}$. Fibroblasts were grown at $41^{\circ} \mathrm{C}$ for seven days prior to FAO-flux assay in order to unmask cell lines expressing thermolabile mutant protein $[24,25]$. Wherever possible we grew and assayed cell lines at $41^{\circ} \mathrm{C}$ where residual oleate flux was $>20 \%$ at $37^{\circ} \mathrm{C}$.

A different mix of normal control cell lines were used for each assay to more broadly reflect general normal control activity under the existing cell culture and laboratory conditions at that time. Internal quality control was achieved by periodically testing stored samples from known patients with a diagnosed fatty acid oxidation disorder. Fibroblast cell lines were low passage, generally passage 3-10, and results were comparable over the study period as results for each assay were expressed as a percentage of simultaneous normal control cell lines grown and assayed under the same conditions. Graphical representation of FAO-flux results is plotted for each patient as the calculated mean percentage activity for all assays for each substrate measured at the stated temperature. Control data is graphically represented by plotted results from a series of control cell lines selected at random. Specific VLCAD activity was measured by the method of Wanders et al. 2010 [15]. Detection of the products $\mathrm{C} 16-\mathrm{CoA}(\mathrm{OH})$ and $\mathrm{C} 16: 1-\mathrm{CoA}$ was by UV-HPLC at $260 \mathrm{~nm}$ following incubation of fibroblast sonicates in $125 \mathrm{mmol} / \mathrm{L}$ Tris-HCL buffer, $0.4 \mathrm{mmol} / \mathrm{L}$ ferrocenium hexafluorophosphate, and $0.25 \mathrm{mmol} / \mathrm{L}$ palmitoyl-CoA at $\mathrm{pH}$ 8.0. Fibroblast protein was by Pierce ${ }^{\mathrm{TM}}$ BCA Protein Assay (Thermo-Scientific, Waltham, MA, USA).

Ethical Standards: All procedures followed were in accordance with ethical standards of the Helsinki Declaration of 1975, as revised in 2000.

\section{Results}

The UV-HPLC enzyme method clearly discriminated VLCADD cell lines from control cell lines in our series of 14 VLCADD patients (Figure 1). Plotting percent oleate flux against VLCAD enzyme activity showed a reasonably good correlation between the two methods with narrow separation between VLCADD patients and all other groups at a cut off value of $\leq 41 \%$ oleate flux at $37^{\circ} \mathrm{C}$ (Figure 2). Seven patients who presented clinically as infants gave enzyme activities of $0.6 \pm 1.0 \mathrm{nmol} / \mathrm{mg} / \mathrm{min}$, normal control activity $14.1 \pm 5.3(n=17)$. However, there was disparity between oleate FAO-flux 
at $37{ }^{\circ} \mathrm{C}$ and the UV-HPLC method at enzyme activities between $20 \%$ and $35 \%$. This manifests as an overlap between cell lines from three myopathic VLCADD patients, two uncategorized patients, one obligate heterozygote and one false positive screen (Figure 1).

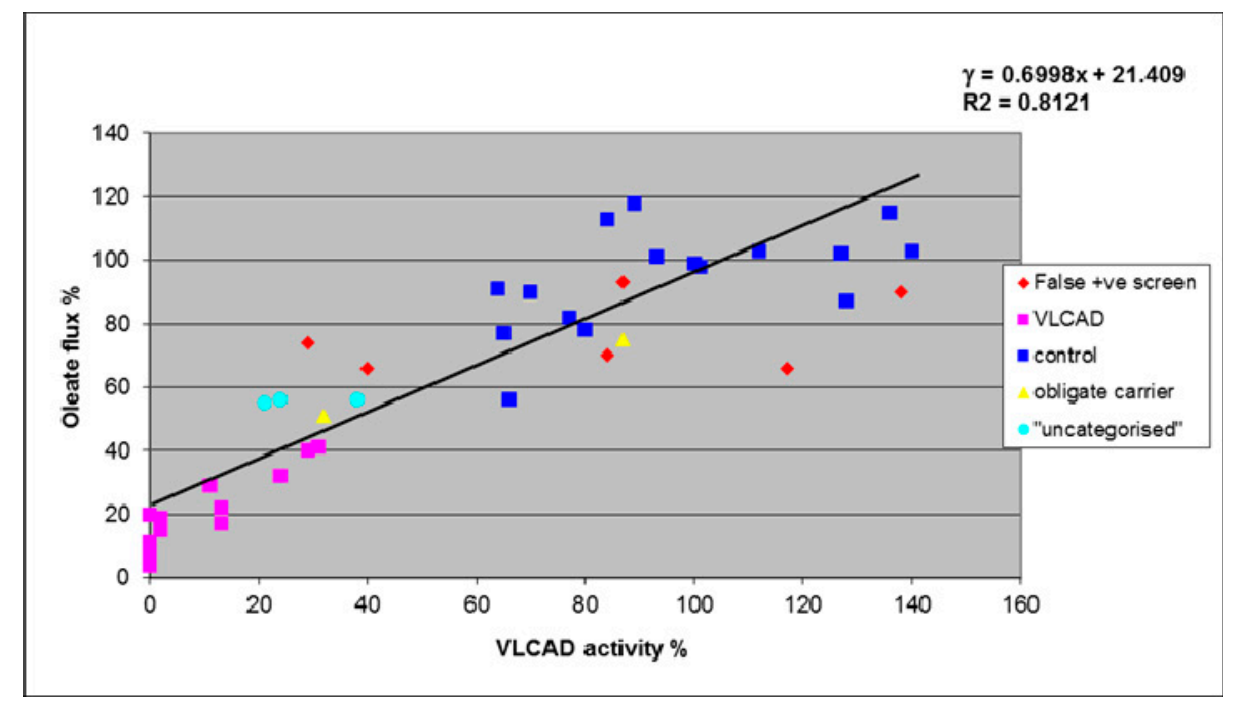

Figure 1. VLCADD percentage activity vs. oleate FAO-flux percentage activity at $37^{\circ} \mathrm{C}$.

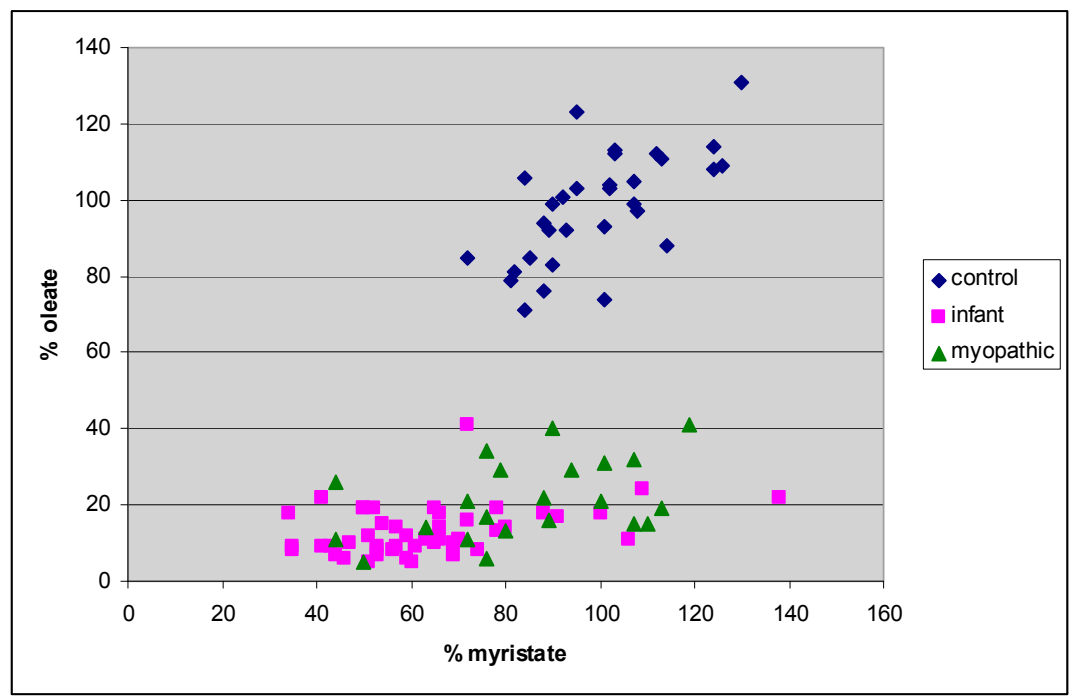

Figure 2. Percentage FAO-flux in infantile and myopathic VLCADD vs. controls at $37^{\circ} \mathrm{C}$.

Results of flux assays at $37^{\circ} \mathrm{C}$ show clear separation of all VLCADD cell lines from controls by plotting percentage oleate FAO-flux against percentage myristate FAO-flux (Figure 2). A degree of separation between infantile and myopathic phenotypes is clearly discernible, although there is some overlap between the two groups.

Plotting fibroblast FAO-flux results obtained at $41^{\circ} \mathrm{C}$ after growing and assaying 19 VLCADD cell lines that exhibited high residual FAO-flux $>20 \%$ at $37^{\circ} \mathrm{C}$ is shown in Figure 3. Control cell lines were also grown and assayed at $41{ }^{\circ} \mathrm{C}$. The results of the VLCADD cell lines with low FAO-flux at $37^{\circ} \mathrm{C}$ are also plotted to demonstrate the merging of the two groups following temperature stress of 19 high residual FAO-flux cell lines. This results in all VLCADD cell lines having an oleate FAO-flux of $\leq 30 \%$ with $60 / 69$ cell lines giving activity of $<20 \%$ (Figure 3 ). 


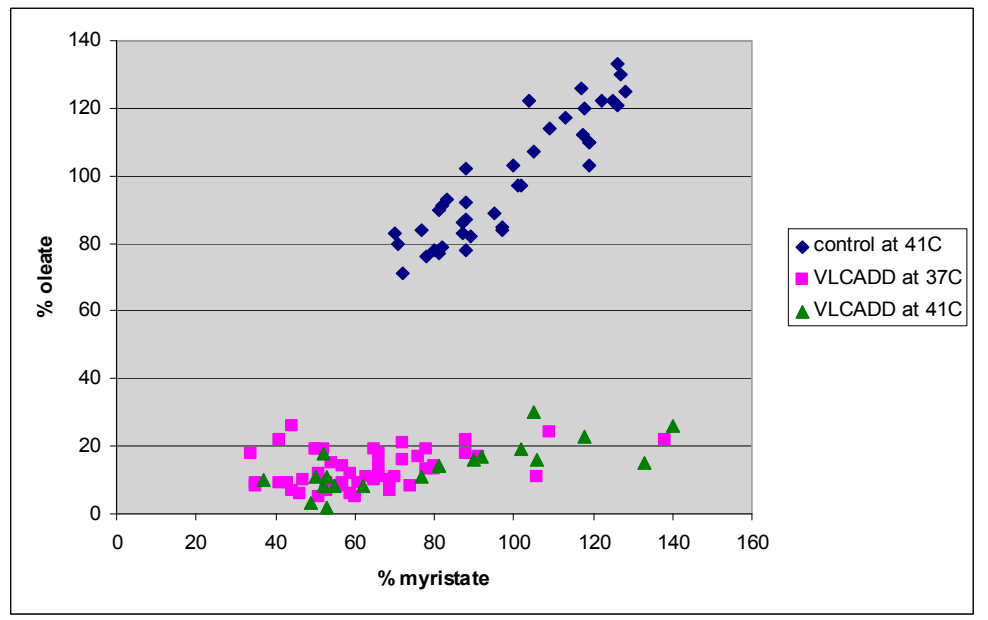

Figure 3. Percentage FAO-flux of high residual activity VLCADD cell lines after exposure to $41{ }^{\circ} \mathrm{C}$ plotted along with results obtained at $37^{\circ} \mathrm{C}$ in VLCADD cell lines with low FAO-flux.

FAO-flux results obtained at $37^{\circ} \mathrm{C}$ in cell lines from 13 positive NBS screened patients (eight false positive, three true positive, and two uncategorized cell lines), two uncategorized adult cell lines and cell lines from four obligate carriers are shown plotted with symptomatic VLCADD cell lines (Figure 4). Details of these patients are set out in Table 1. All eight of the false positive NB screened infant cell lines are clearly separated from the symptomatic VLCADD cell lines and segregate with/towards the normal control group (Figure 4). The three true positive screened cell lines segregate with the clinically symptomatic VLCADD group. Three of the adult obligate heterozygotes (cell lines 32,33 , and 35) give FAO-flux of $107 \%, 103 \%$ and $71 \%$, respectively, and segregate with the normal control group. Two uncategorized positive screened infants (cell lines 16 and 22), both compound heterozygous for the "mild" c. $1226 \mathrm{C}>\mathrm{T}$ mutation plus a second mutation, gave oleate FAO-flux of $63 \%$ and $56 \%$, respectively, which plot between the VLCADD and normal control groups. Two cell lines from two adults (cell lines 52 and 19) with clinical symptoms possibly attributable to reduced VLCAD activity and one of the obligate heterozygotes (cell line 34) gave FAO-flux activity of 56\%, 55\% and $51 \%$, respectively, which again plots between the clinically affected and the normal control group.

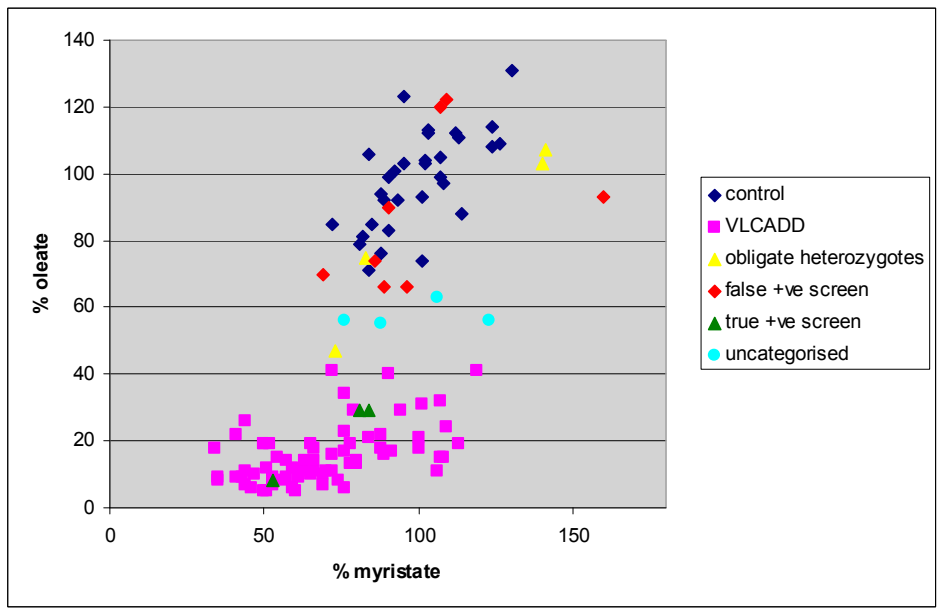

Figure 4. Percentage FAO-flux in VLCADD, obligate heterozygotes, false positive, true positive screened infants and four uncategorized cell lines at $37^{\circ} \mathrm{C}$ as compared to normal controls.

The FAO-flux results for the cell lines listed in Table 1 following growth and assay at $41{ }^{\circ} \mathrm{C}$ are plotted along with the symptomatic VLCADD group (Figure 5). The highest percent oleate FAO-flux 
in a cell line from a symptomatic VLCADD patient derived at $41{ }^{\circ} \mathrm{C}$ is $30 \%$ and most $(60 / 69)$ VLCADD patient cell lines have FAO-flux activity $<20 \%$. The uncategorized positive screen (cell line 22) that gave $56 \%$ oleate flux at $37^{\circ} \mathrm{C}$ shows reduction of activity at $41{ }^{\circ} \mathrm{C}$ to $21 \%$ and now segregates with the symptomatic VLCADD group. The two uncategorized adults (cell lines 52 and 19) only show relatively small reductions in FAO-flux at $41{ }^{\circ} \mathrm{C}$ both giving oleate flux of $46 \%$ and remain segregated roughly equidistant between the normal control group and symptomatic VLCADD group. The obligate heterozygote (cell line 34) gives an oleate FAO-flux of 52\%, which again plots between the normal control group and the symptomatic VLCADD cell lines. However, all three cell lines do not segregate with the symptomatic VLCADD group and would therefore be considered as "low risk" patients with regards to developing clinical symptoms related to VLCAD deficiency.

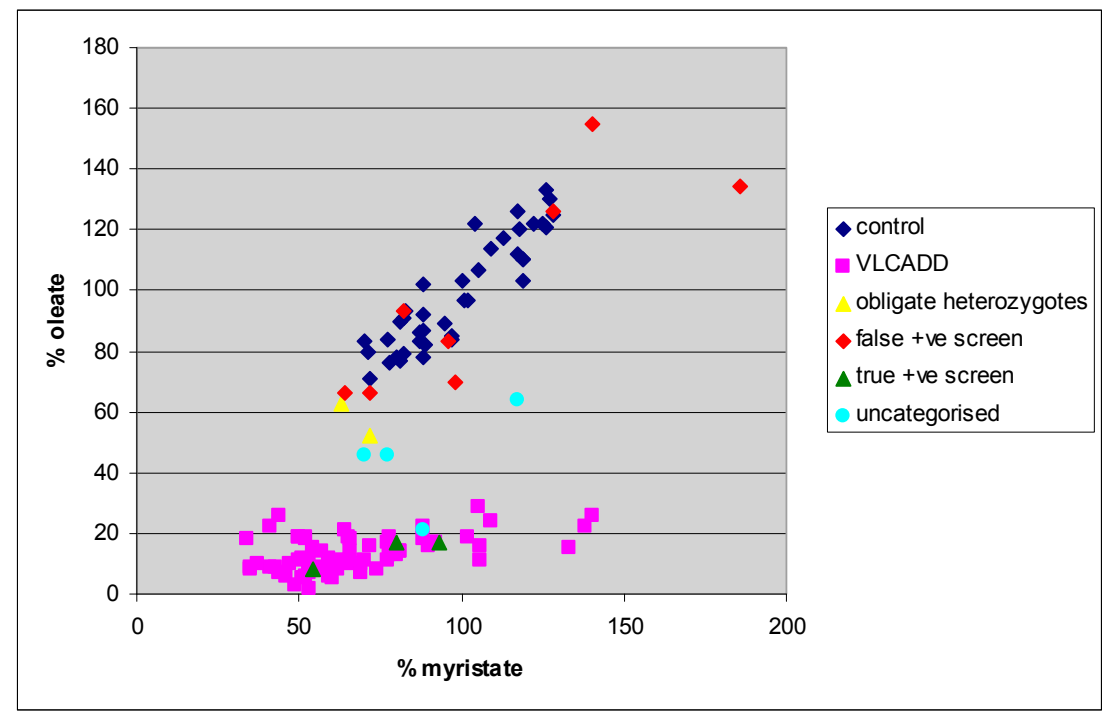

Figure 5. Percentage FAO-flux in VLCADD, obligate heterozygotes, false positive, true positive screened infants and uncategorized cell lines at $41^{\circ} \mathrm{C}$.

\section{Discussion}

We have measured fatty acid oxidation flux in over 7000 patient cell lines over the past 25 years using the substrates $\left[9,10-\mathrm{H}^{3}\right]$ myristic acid, $\left[9,10-\mathrm{H}^{3}\right]$ palmitic acid and $\left[9,10-\mathrm{H}^{3}\right]$ oleic acid. In this study, we have only reported myristate and oleate FAO-flux as these two substrates alone provide the necessary relevant information for the diagnosis of VLCADD. Currently, we perform FAO-flux assays on approximately 340 cell lines annually.

We have a confirmed diagnosis of VLCADD in 69 symptomatic patients and most have molecular confirmation with the finding of two mutations in the ACADVL gene. However, specific details of mutations are not available for all patients. In this study, we have compared results of the VLCAD enzyme assay to oleate FAO-flux assay at $37^{\circ} \mathrm{C}$ in a limited number of patients. Although there was relatively good correlation between the two assays, there was a clear indication that the enzyme assay in fibroblasts could not separate some heterozygotes from cell lines obtained from clinically symptomatic VLCADD patients at enzyme activities of approximately $20 \%$ to $35 \%$ of the control mean. Inconclusive classification of patients using molecular and biochemical assays including the use of a similar enzyme assay in lymphocytes have previously been reported $[11,26]$. An example of such disparity in the present study was that one symptomatic VLCADD cell line (Figure 1) gave enzyme activity of 31\%, while a false positive screen infant (cell line 91) and an obligate heterozygote (cell line 34) gave enzyme activity of $32 \%$ and $29 \%$, respectively (Figure 1,Table 1). The VLCADD patient in question had a high residual oleate FAO-flux of $41 \%$ at $37^{\circ} \mathrm{C}$ (Figure 2), but this fell to $15 \%$ at $41^{\circ} \mathrm{C}$, which clearly identified her as an "at risk" VLCADD patient. This same patient was diagnosed with 
VLCADD in her 60s and shown to have two known pathogenic mutations in ACADVL gene. She had suffered with repeated episodes of rhabdomyolysis since childhood but was well between episodes with normal creatine kinase and normal muscle strength.

In this study, we have graphically plotted the percent FAO-flux of cell lines from symptomatic VLCADD patients and shown that these are clearly separated from normal control cell lines both at 37 and $41^{\circ} \mathrm{C}$ (Figures 1 and 2). This provides us with data with which to compare NBS positive infants and allows us to ascribe a degree of clinical risk for each presumptive positive patient. However, we do not know if all patient that segregate with the clinically affected groups will develop symptomatic disease, as many factors may influence clinical expression of the defect $[7,27]$ and it is suggested that some patients with high residual enzyme activity even with two mutations may remain asymptomatic $[11,16]$. However, using myristate and oleate FAO-flux, we have clearly segregated eight false positive screen patients with the control group and three true positives with the symptomatic VLCADD group. We have also shown that by incubating and assaying fibroblasts at $37^{\circ} \mathrm{C}$ and in the case of two obligate heterozygote cell lines, also at $41^{\circ} \mathrm{C}$, we have segregated four asymptomatic adult obligate heterozygotes away from the symptomatic VLCADD cell lines. In addition, in the present study, results of cell lines from two symptomatic adults, although not segregating with the clinically presenting VLCADD cases, plotted equidistant between the controls and symptomatic VLCADD cell lines. This indicates that, in some patients, there may remain some unresolved questions as to any likely contribution of a moderate reduction in VLCAD activity to the development of clinical disease.

Interestingly two screen positive infants carrying the "benign" Pacific mutation c.1226C $>\mathrm{T}$ plus a second mutation gave somewhat equivocal oleate flux results at $37{ }^{\circ} \mathrm{C}$ of $63 \%$ and $56 \%$, respectively (Table 1), which would suggest a relatively low risk, as these did not segregate within the symptomatic VLCADD group. On stressing the fibroblasts at $41{ }^{\circ} \mathrm{C}$, however, cell line 22 segregated with the symptomatic VLCADD group while cell line 16 segregated with the normal controls (Figure 5). This could be explained by their second mutation. Cell line 22 carries the c.1322G>A (p.Gly441Asp) mutation, which has been reported in several clinically affected infants $[8,9,28,29]$, whereas patient 16 has the c.1616C $>$ A (p.Ala539Asp) mutation, which has not been reported in clinically affected patients and is at present a variant of unknown clinical significance. Both patients remain well however and have been discharged (Table 1).

We know of one young adult patient in our series (data not plotted) who remained asymptomatic despite his younger sister presenting primarily with a myopathic phenotype, although both patients carried the same mutations and had similarly low flux results (oleate flux at $41{ }^{\circ} \mathrm{C}$ of $23 \%$ and $26 \%$, respectively). The concern that over-diagnosing patients who may not have clinical problems until adolescence or adulthood or indeed at all, is a legitimate concern [30]. However, several patients that have been diagnosed as "myopathic" VLCADD in this study have, on closer investigation of their clinical record, been reported as presenting as infants or young children with one or several episodes of hypoglycemia. This supports the idea that even "milder" phenotypes may present in infancy given sufficient metabolic stress. Equally although most infantile phenotypes in this study had low oleate flux at $37^{\circ} \mathrm{C}$ i.e., $42 / 46<20 \%$, one infant who presented with an episode of low blood glucose gave a high residual oleate flux of $41 \%$ at $37^{\circ} \mathrm{C}$ (Figure 2), however this fell to $11 \%$ at $41{ }^{\circ} \mathrm{C}$. This might also indicate that given sufficient metabolic stress in infancy/childhood there may be precipitation of hypoglycemic crisis even in some patients with significant residual enzyme function. We would suggest that it is important to identify even potentially mild phenotypes to avoid the possibility of metabolic decompensation and serious clinical sequelae. Similarly, in the case of MCADD, it is widely accepted that not all patients homozygous for the common c.985A $>\mathrm{G}$ mutation will present with clinical disease during their life time although MCADD is universally accepted as fitting the recognized newborn screening criteria [31]. 


\section{Conclusion}

The combined use of $\left[9,10-\mathrm{H}^{3}\right]$ myristic acid and $\left[9,10-\mathrm{H}^{3}\right]$ oleic acid FAO-flux at both $37^{\circ} \mathrm{C}$ and $41{ }^{\circ} \mathrm{C}$ will separate clinically symptomatic VLCADD patients from simple heterozygotes and offers a reliable way of ascribing a degree of clinical risk in NB screen positive infants where other biochemical and molecular markers are inconclusive. In addition, plotting results of FAO-flux data obtained at $37^{\circ} \mathrm{C}$ provides useful information with regards to the likely clinical phenotype of the patient.

Acknowledgments: We would like to thank H. Hind for her valuable contribution in the tissue culture of fibroblast cell lines.

Author Contributions: Simon E. Olpin and Rodney J. Pollitt conceived \& designed the FAO-flux assays. Shirley Clark, Simon E. Olpin, Jane Dalley, Joanne Croft, Camilla A. Scott, Nigel J. Manning performed the assays Aneal Khan, Emma Glamuzina, Alicia Chan, Rebecca Sparkes and Marisa Chard had direct clinical contact with \& provided the samples from the NB screened patients. Brage S. Andresen, Richard J. Kirk \& Jean Bastin provided molecular confirmation of patients. Simon E. Olpin wrote the manuscript.

Conflicts of Interest: The authors declare no conflict of interest.

\section{References}

1. Bennett, M.J. Newborn screening for metabolic diseases: Saving children's lives and improving outcomes. Clin. Biochem. 2014, 47, 693-694. [CrossRef] [PubMed]

2. Pollak, A.; Kasper, D.C. Austrian Newborn Screening Program: A perspective of five decades. J. Perinat. Med. 2014, 42, 151-158. [CrossRef] [PubMed]

3. Coman, D.; Bhattacharya, K. Extended newborn screening: An update for the general paediatrician. J. Paediatr. Child Health 2012, 48, E68-E72. [CrossRef] [PubMed]

4. Scaturro, G.; Sanfilippo, C.; Piccione, M.; Piro, E.; Giuffrè, M.; Corsello, G. Newborn screening of inherited metabolic disorders by tandem mass spectrometry: Past, present and future. Pediatr. Med. Chir. 2013, 35, 105-109. [CrossRef] [PubMed]

5. Ryder, B.; Knoll, D.; Love, D.R.; Shepherd, P.; Love, J.M.; Reed, P.W.; de Hora, M.; Webster, D.; Glamuzina, E.; Wilson, $\mathrm{C}$. The natural history of elevated tetradecenoyl-L-carnitine detected by newborn screening in New Zealand: Implications for very long chain acyl-CoA dehydrogenase deficiency screening and treatment. J. Inherit. Metab. Dis. 2016, 39, 409-414. [CrossRef] [PubMed]

6. Leal, J.; Wordsworth, S.; Oerton, J.; Khalid, J.M.; Dezateux, C. Synthesis framework estimating prevalence of MCADD and sensitivity of newborn screening programme in the absence of direct evidence. J. Clin. Epidemiol. 2014, 67, 1131-1138. [CrossRef] [PubMed]

7. Olpin, S.E. Pathophysiology of fatty acid oxidation disorders and resultant phenotypic variability. J. Inherit. Metab. Dis. 2013, 36, 645-658. [CrossRef] [PubMed]

8. Andresen, B.S.; Olpin, S.; Poorthuis, B.J.H.M.; Scholte, H.R.; Vianey-Saban, C.; Wanders, R.; Ijlst, L.; Morris, A.; Pourfarzam, M.; Bartlett, K.; et al. Clear correlation of genotype with disease phenotype in very long-chain Acyl-CoA dehydrogenase deficiency. Am. J. Hum. Genet. 1999, 64, 479-494. [CrossRef] [PubMed]

9. Evans, M.; Andresen, B.S.; Nation, J.; Boneh, A. VLCAD deficiency: Follow-up and outcome of patients diagnosed through newborn screening in Victoria. Mol. Genet. Metab. 2016, 118, 282-287. [CrossRef] [PubMed]

10. Merritt, J.L.; Vedal, S.; Abdenur, J.E.; Au, S.M.; Barshop, B.A.; Feuchtbaum, L.; Harding, C.O.; Hermerath, C.; Lorey, F.; Sesser, D.E.; et al. Infants suspected to have very-long chain acyl-CoA dehydrogenase deficiency from newborn screening. Mol. Genet. Metab. 2014, 111, 484-492. [CrossRef] [PubMed]

11. Hoffmann, L.; Haussmann, U.; Mueller, M.; Spiekerkoetter, U. VLCAD enzyme activity determinations in newborns identified by screening: A valuable tool for risk assessment. J. Inherit. Metab. Dis. 2012, 35, 269-277. [CrossRef] [PubMed]

12. Spiekerkoetter, U.; Mueller, M.; Sturm, M.; Hofmann, M.; Schneider, D.T. Lethal undiagnosed very long-chain Acyl-CoA dehydrogenase deficiency with mild c14-acylcarnitine abnormalities on newborn screening. JIMD Rep. 2012, 6, 113-115. [PubMed] 
13. Spiekerkoetter, U.; Sun, B.; Zytkovicz, T.; Wanders, R.; Strauss, A.W.; Wendel, U. MS/MS-based newborn and family screening detects asymptomatic patients with very-long-chain acyl-CoA dehydrogenase deficiency. J. Pediatr. 2003, 143, 335-342. [CrossRef]

14. Ventura, F.V.; Costa, C.G.; Struys, E.A.; Ruiter, J.; Allers, P.; Ijlst, L.; Tavares de Almeida, I.; Duran, M.; Jakobs, C.; Wanders, R. Quantitative acylcarnitine profiling in fibroblasts using $\left[\mathrm{U}-{ }^{13} \mathrm{C}\right]$ palmitic acid: An improved tool for the diagnosis of fatty acid oxidation defects. Clin. Chim. Acta 1999, 281, 1-17. [CrossRef]

15. Wanders, R.J.A.; Ruiter, J.P.N.; Ijlst, L.; Waterham, H.R.; Houten, S.M. The enzymology of mitochondrial fatty acid beta-oxidation and its application to follow-up analysis of positive neonatal screening results. J. Inherit. Metab. Dis. 2010, 33, 479-494. [CrossRef] [PubMed]

16. Spiekerkoetter, U.; Haussmann, U.; Mueller, M.; ter Veld, F.; Stehn, M.; Santer, R.; Lukacs, Z. Tandem mass spectrometry screening for very long-chain acyl-CoA dehydrogenase deficiency: The value of second-tier enzyme testing. J. Pediatr. 2010, 157, 668-673. [CrossRef] [PubMed]

17. Schymik, I.; Liebig, M.; Mueller, M.; Wendel, U.; Mayatepek, E.; Strauss, A.W.; Wanders, R.J.A.; Spiekerkoetter, U. Pitfalls of neonatal screening for very-long-chain acyl-CoA dehydrogenase deficiency using tandem mass spectrometry. J. Pediatr. 2006, 149, 128-130. [CrossRef] [PubMed]

18. Olpin, S.E.; Manning, N.J.; Pollitt, R.J.; Clarke, S. Improved detection of long-chain fatty acid oxidation defects in intact cells using $\left[9,10-{ }^{3} \mathrm{H}\right]$ oleic acid. J. Inherit. Metab. Dis. 1997, 20, 415-419. [CrossRef] [PubMed]

19. Olpin, S.E.; Manning, N.J.; Pollitt, R.J.; Bonham, J.R.; Downing, M.; Clark, S. The use of $\left[9,10-{ }^{3} \mathrm{H}\right] \mathrm{myristate}$, $\left[9,10-{ }^{3} \mathrm{H}\right]$ palmitate and $\left[9,10-{ }^{3} \mathrm{H}\right]$ oleate for the detection and diagnosis of medium and long-chain fatty acid oxidation disorders in intact cultured fibroblasts. Adv. Exp. Med. Biol. 1999, 466, 321-325. [PubMed]

20. Olpin, S.E.; Clark, S.; Scott, C.; Manning, N.J.; Bonham, J.R.; Hind, H.; Andresen, B.S.; Khan, A.; Sharma, R.; Kirk, R.; et al. Diagnosing very long-chain acyl-CoA dehydrogenase deficiency (VLCAD). J. Inherit. Metab. Dis. 2012, 35 O-043 (Suppl 1), S15.

21. Diekman, E.F.; Ferdinandusse, S.; van der Pol, L.; Waterham, H.R.; Ruiter, J.P.N.; Ijlst, L.; Wanders, R.J.; Houten, S.M.; Wijburg, F.A.; Blank, A.C.; et al. Fatty acid oxidation flux predicts the clinical severity of VLCAD deficiency. Genet. Med. 2015, 17, 989-994. [CrossRef] [PubMed]

22. Manning, N.J.J.; Olpin, S.E.E.; Pollitt, R.J.J.; Webley, J. A comparison of $\left[9,10-{ }^{3} \mathrm{H}\right]$ palmitic and $\left[9,10-{ }^{3} \mathrm{H}\right]$ myristic acids for the detection of defects of fatty acid oxidation in intact cultured fibroblasts. J. Inherit. Metab. Dis. 1990, 13, 58-68. [CrossRef] [PubMed]

23. Olpin, S.E.; Manning, N.J.; Carpenter, K.; Middleton, B.; Pollitt, R.J. Differential diagnosis of hydroxydicarboxylic aciduria based on release of $3 \mathrm{H}_{2} \mathrm{O}$ from $\left[9,10-{ }^{3} \mathrm{H}\right]$ myristic and $\left[9,10-{ }^{3} \mathrm{H}\right]$ palmitic acids by intact cultured fibroblasts. J. Inherit. Metab. Dis. 1992, 15, 883-890. [CrossRef] [PubMed]

24. Li, H.; Fukuda, S.; Hasegawa, Y.; Kobayashi, H.; Purevsuren, J.; Mushimoto, Y.; Yamaguchi, S. Effect of heat stress and bezafibrate on mitochondrial $\beta$-oxidation: Comparison between cultured cells from normal and mitochondrial fatty acid oxidation disorder children using in vitro probe acylcarnitine profiling assay. Brain Dev. 2010, 32, 362-370. [CrossRef] [PubMed]

25. O'Reilly, L.; Bross, P.; Corydon, T.J.; Olpin, S.E.; Hansen, J.; Kenney, J.M.; McCandless, S.E.; Frazier, D.M.; Winter, V.; Gregersen, N.; et al. The $\mathrm{Y} 42 \mathrm{H}$ mutation in medium-chain acyl-CoA dehydrogenase, which is prevalent in babies identified by MS/MS-based newborn screening, is temperature sensitive. Eur. J. Biochem. 2004, 271, 4053-4063. [CrossRef] [PubMed]

26. Liebig, M.; Schymik, I.; Mueller, M.; Wendel, U.; Mayatepek, E.; Ruiter, J.; Strauss, A.W.; Wanders, R.J.A.; Spiekerkoetter, U. Neonatal screening for very long-chain acyl-CoA dehydrogenase deficiency: Enzymatic and molecular evaluation of neonates with elevated C14:1-carnitine levels. Pediatrics 2006, 118, 1065-1069. [CrossRef] [PubMed]

27. Gregersen, N.; Andresen, B.S.; Corydon, M.J.; Corydon, T.J.; Olsen, R.K.J.; Bolund, L.; Bross, P. Mutation analysis in mitochondrial fatty acid oxidation defects: Exemplified by acyl-CoA dehydrogenase deficiencies, with special focus on genotype-phenotype relationship. Hum. Mutat. 2001, 18, 169-189. [CrossRef] [PubMed]

28. Andresen, B.S.; Vianey-Saban, C.; Bross, P.; Divry, P.; Roe, C.R.; Nada, M.A.; Knudsen, I.; Gregersen, N. The mutational spectrum in very long-chain acyl-CoA dehydrogenase deficiency. J. Inherit. Metab. Dis. 1996, 19, 169-172. [CrossRef] [PubMed]

29. Mathur, A.; Sims, H.F.; Gopalakrishnan, D.; Gibson, B.; Rinaldo, P.; Vockley, J.; Hug, G.; Strauss, A.W. Molecular heterogeneity in very-long-chain acyl-CoA dehydrogenase deficiency causing pediatric cardiomyopathy and sudden death. Circulation 1999, 99, 1337-1343. [CrossRef] [PubMed] 
30. Bonham, J.R. Impact of new screening technologies: Should we screen and does phenotype influence this decision? J. Inherit. Metab. Dis. 2013, 36, 681-686. [CrossRef] [PubMed]

31. Rhead, W.J. Newborn screening for medium-chain acyl-CoA dehydrogenase deficiency: A global perspective. J. Inherit. Metab. Dis. 2006, 29, 370-377. [CrossRef] [PubMed]

(C) 2017 by the authors. Licensee MDPI, Basel, Switzerland. This article is an open access article distributed under the terms and conditions of the Creative Commons Attribution (CC BY) license (http:/ / creativecommons.org/licenses/by/4.0/). 